\title{
THE ROLE OF COLLABORATIVE LEARNING IN TEACHING FOREIGN LANGUAGES TO NON-LINGUISTIC STUDENTS
}

Chyzhykova Olha, $\mathrm{PhD}$ in Pedagogical Sciences, Associate Professor at the Department of Foreign and Business Ukrainian Languages, State University of Economics and Technology. ORCID: 0000-0002-4432-9743

E-mail: olgalehina@ukr.net

The article analyzes the current stage of foreign language study in higher educational establishments. Student interaction and collaboration are considered as essential elements in the development of communication skills. Principal approaches to the definition of collaborative learning are analyzed in the article.

The author analyzes advantages of collaborative learning in the process of foreign language study, including development of students' communicative abilities and active participation in the learning process, fostering learners' autonomy and creative thinking skills, development of students' selflearning and cooperation abilities.

A detailed description of collaborative learning activities in the process of teaching English to nonlinguistic students is presented in the article.

Keywords: collaborative learning, collaboration learning activities, student interaction, teaching a foreign language, non-linguistic students, teaching strategies, learning in cooperation, work in group, educational technology.

\section{РОЛЬ НАВЧАННЯ У СПІВРОБІТНИЦТВІ В ПРОЦЕСІ ВИВЧЕННЯ ІНОЗЕМНИХ МОВ СТУДЕНТАМИ НЕМОВНИХ СПЕЦАЛЬНОСТЕЙ}

Чижикова Ольга, кандидат педагогічних наук, доцент кафедри іноземних та ділової української мов, Державний університет економіки і технологій.

ORCID: 0000-0002-4432-9743

E-mail: olgalehina@ukr.net

У статті проаналізовано сучасний етап викладання іноземної мови у закладах вищої освіти. Взаємодія та співпрачя студентів окреслені як важливі елементи розвитку іншомовних комунікативних здібностей студентів. У статті проаналізовано різні наукові підходи до визначення навчання у співробітництві.

Автор аналізує переваги навчання у співробітництві в процесі вивчення іноземної мови, включно з розвитком комунікативних здібностей, активною участю студентів у процесі навчання, розвитком автономії та творчого мислення студентів, здатністю майбутніх фахівців до самонавчання та співпраці. У статті розглядаються основні характеристики навчання у співробітництві в процесі вивчення іноземної мови. Розкрито спеціальні принципи, етапи та особливості впровадження навчання у співробітництві під час вивчення іноземної мови студентами нелінгвістичних спеціальностей. Особлива увага приділяється розвитку комунікативних навичок, активній участі студентів у мовленнєвій діяльності, практичному опануванню професійної термінології, розвитку творчих здібностей студентів.

Представлено детальний опис видів діяльності у малих групах у процесі викладання англійської 
мови студентам нелінгвістичних спеціальностей. Розв'язання проблем, групові проєкти, дискусї в малих групах спрямовані на розвиток критичного мислення, навичок діалогічного мовлення, творчих здібностей майбутніх фахівців.

У статті наведено рекомендації для викладачів та студентів щзодо успішного впровадження навчання у співробітництві в процесі вивчення іноземної мови. Доцільно використовувати новітні технологї та методи викладання англійської мови, застосовувати інформаційні технологї під час навчання, створити творчу атмосферу на заняттях та сприятливе для студентів іншомовне середовище для успішної реалізації навчання у співробітництві.

Ключові слова: навчання у співробітництві, інтеракція студентів, викладання іноземної мови, студенти нелінгвістичних спеціальностей, навчальні стратегії, навчання у співпраці, робота в групі, педагогічні технологї.

The field of foreign language teaching and learning has undergone great changes at the present stage. The process of learning foreign languages has become learner-centered, where students play an active role. Thus interaction and collaboration are considered as significant elements for improving language learning. Instead of being knowledge consumers, who passively acquire knowledge, students are now seen as active participants of the learning process. They develop communicative ability directly and apply knowledge in practical situations. Moreover, they actively take part in the process of knowledge production, express their own ideas, discuss and brainstorm, generate creative ideas.

In scientific research it is rightly stressed that "the teachers have to implement various effective teaching strategies to inspire the learners during classroom teaching" [7]. Collaborative learning strategies in their turn aim to "develop interdependence among group members, active participation, interactive dialogue, and co-creation of academic products" [11]. Therefore, building a creative atmosphere during the learning process is of great importance, as students feel more comfortable, collaborate, express ideas and take responsibility for their decisions. So, collaborative learning can be viewed as an effective means of students' autonomy development, students' interaction and mastering of foreign language competence.

Student collaborative activity is one of the central issues of modern scientific researches. Thus, the main features of collaborative learning and student interaction are investigated by M. Bevilacqua, R. Ellis, S. Ghodsi, M. Laal, J. MacGregor, R. Parupalli, L. Sousa, F. Tiraboschi, N. do Lago, F. de Figueiredo, Y. Zhang etc. Principles, stages, types of collaborative activities have been studied by such Ukrainian scientists as M. Hladun, L. Pinchuk, H. Prystai, M. Sablina, S. Sysoieva etc. Main characteristics, benefits, rules and factors that positively influence successful collaborative learning usage have been explored by M. Bevilacqua, S. Kozhushko, M. Laal, L. Lebedik, R. Parupalli, I. Chepurko and others.

Thus, S. Sysoieva pays special attention to collaborative learning as interactive technology which corresponds to the ideology of personality-oriented learning. She investigated the main principles and types (different variants) of training in a team (group), including collaboration learning in small groups, team and game activities, individual work in teams, jigsaw, "learning together" and students' research work in groups [3]. Cooperative learning as a component of personality-oriented approach and an effective pedagogical technology has been studied by M. Hladun, L. Pinchuk and M. Sablina. Thus, M. Hladun and M. Sablina also viewed pedagogical technology of "learning in cooperation" as an integral part of the personality-oriented approach, which is aimed to foster students' motivation, develop the necessary competencies by students' active interaction in the educational process. 
The authors analyzed the growing role of information technologies in the process of training in cooperation [1].

The importance of collaborative learning approach in English classes is studied by F. de Figueiredo, N. Ibrahim, N. do Lago, L. Pinchuk, H. Prystai, R. Parupalli, L. Sousa, F. Tiraboschi. This approach allows to learn through activities based on group work (learning cells, buzz groups, clusters, fishbowl debates, round robin). The authors singled out benefits of the approach, including open communication, mutual cooperation and self-management skills development. Peculiarities of cooperative learning in teaching English as a second foreign language has been studied by L. Pinchuk. The author described such innovative technologies as project method and Language Portfolio [2].

In spite of the numerous scientific studies devoted to collaborative learning, the specific peculiarities of its implementation in the process of learning a foreign language for specific purposes by non-linguistic students is not fully highlighted.

The purpose of the proposed study is to analyze the role and main characteristics of collaborative learning in teaching a foreign language to non-linguistic students at the present stage.

The collaborative learning strategy makes the learning process active and meaningful for learners themselves. Students work together in groups to achieve the learning goals, provide the academic support to each other, brainstorm and co-operate, share responsibility for the decisions taken and reflect on the learning result.

In scientific studies collaborative learning is defined as "an umbrella term for a variety of educational approaches involving joint intellectual effort by either the learners or the learners and teachers together" [7]; technology which "aims to co-construct knowledge, and that might result in linguistic changes" [6]; an integral part of the personality-oriented approach in teaching $[1 ; 2]$.

Collaborative learning has the following characteristics: a) focus on the learning process and on students and their interaction; b) implementation of activities that allow students to perform different roles during foreign language study; c) students' active roles in the learning process; d) the learning process is viewed as a shared experience among its participants; e) the development of social and cognitive skills, f) creation of an environment, in which learners' interdependence is supported, g) promotion of students' autonomy, selfregulation and self-esteem [10].

M. Bevilacqua suggests such rules of a successful collaboration as designing specific roles, making students responsible for their activity and learning results, monitoring the process of group progress etc [4].

Among the advantages of collaborative learning in English language environment the researchers underline the learners' ability to participate actively in conversations and dialogues, decrease of dependence on teachers, development of students' communicative abilities, promotion of more active and responsible role of students in obtaining knowledge [5]; a possibility to meet the learners' individual needs and purposes [7]; providing mutual support, the opportunity to generate numerous creative ideas [10]; development of problemsolving skills and social relationships among the students, promotion of learners' self-learning abilities and cooperation within the groups, turning more difficult tasks into simple ones, stimulation of learners' motivation, expressing and clarifying students' ideas through debates and discussions, development of students' leadership qualities and rational thinking 
enrichment, improving learners' mental ability and students' practical knowledge [8]. Moreover, collaboration fosters creating a positive atmosphere for practicing learners' cooperation, reduces learners' anxiety and stress, eliminates the fear to get a wrong answer, and develops critical thinking skills.

M. Laal and S. M. Ghodsi underlined such benefits of collaborative learning as: social benefits (creation of a friendly atmosphere for modelling and practicing cooperation, support for learners); psychological benefits (positive influence on students' self-esteem, reduction of anxiety); academic benefits (development of critical thinking skills; active students' participation) [6].

K. Scager et al. distinguished two groups of "factors that contributed to the effectiveness of the collaboration: 1) design factors: the design of the course and the assignment (students' autonomy, task characteristics, teacher expectations, group size); 2) process factors: the way students interact (team and task regulation, interdependence, interaction, mutual support, motivation)" [9].

On the other hand, the participants of the learning process may face a number of disadvantages, such as "disagreements and conflicts they had to handle during the interactions" [10].

R. Parupalli offers to use various activities, such as role plays, think-pair-share, group projects, debates, group and pair activities, case-based learning, classroom problems as examples of collaborative activities [8].

In our research we singled out specific features of collaborative learning implementation in the process of learning a foreign language for specific purpose by nonlinguistic students: focus on communicative skills development, students' participation in foreign language speaking activities, practical usage of professional (business) terminology, facilitation of students' motivation to learn foreign languages, development of students' creative abilities.

\begin{tabular}{|c|c|c|}
\hline $\begin{array}{l}\text { Defining the objectives, topic, of the } \\
\text { lesson; }\end{array}$ & $\Leftrightarrow$ & $\begin{array}{l}\qquad \text { Principles } \\
\text { development of communication skills; } \\
\text { designing specific roles; } \\
\text { personal responsibility of the achieved results; } \\
\text { facilitating students' creative idea generation; } \\
\text { equal possibilities for students to achieve success. }\end{array}$ \\
\hline Selection of educational material; & & II \\
\hline Group formation, choosing the roles & & $\begin{array}{l}\text { Collaborative foreign language learning by non- } \\
\text { linguistic students }\end{array}$ \\
\hline among the participants; & & II \\
\hline $\begin{array}{l}\text { Monitoring the progress of the } \\
\text { groups' activity; } \\
\text { Discussion of the achieved results; } \\
\text { reflection and evaluation. }\end{array}$ & 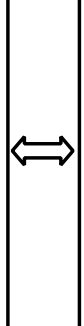 & $\begin{array}{l}\text { Conditions } \\
\text { learner-centered process of learning foreign languages; } \\
\text { active students' participation and interaction; } \\
\text { focus on students' productive activity; } \\
\text { possibility of independent knowledge acquisition; } \\
\text { applying theoretical knowledge in practical } \\
\text { communicative situations; } \\
\text { developments of foreign language communication skills. }\end{array}$ \\
\hline
\end{tabular}

Picture 1. Collaborative learning in the process of learning foreign languages by non-linguistic students 
Collaborative learning activities have been successfully implemented in English classes at State University of Economics and Technology. Such types of activities as brainstorming, group problem-solving, team-based learning (learning in teams), group projects, and discussions in small groups are presented in Table 1.

\section{Collaborative learning activities of non-linguistic students in the process of foreign language study}

\begin{tabular}{|c|c|c|c|}
\hline $\begin{array}{c}\text { Types of } \\
\text { collaborative } \\
\text { learning activities }\end{array}$ & Level of English & $\begin{array}{c}\text { Stages of organization of collaborative } \\
\text { activity in the group }\end{array}$ & $\begin{array}{l}\text { Skills to be } \\
\text { developed }\end{array}$ \\
\hline Brainstorming & $\begin{array}{c}\text { Elementary, } \\
\text { Pre-Intermediate, } \\
\text { Intermediate }\end{array}$ & $\begin{array}{l}\text { 1. A teacher presents a lexical unit of professionally } \\
\text { oriented vocabulary (franchising, corporation, } \\
\text { royalty payment, business plan etc.). } \\
\text { 2. Students present as many verbal associations with } \\
\text { the word combination as possible. } \\
\text { 3. A teacher formulates an educational problem } \\
\text { connected with the given lexical unit. } \\
\text { 4. Students generate ideas on how to solve a problem } \\
\text { and estimate the best possible variants. }\end{array}$ & $\begin{array}{l}\text { critical thinking } \\
\text { skills, lexical } \\
\text { skills, creative } \\
\text { idea generation, } \\
\text { rational thinking } \\
\text { skills }\end{array}$ \\
\hline $\begin{array}{l}\text { Group } \\
\text { problem-solving }\end{array}$ & $\begin{array}{l}\text { Pre-Intermediate, } \\
\text { Intermediate }\end{array}$ & $\begin{array}{l}\text { 1. Students are presented with a problem and given } \\
\text { guidance (minimal instructions) toward solving } \\
\text { the problem. } \\
\text { 2. Students brainstorm in groups and present their } \\
\text { solutions. } \\
\text { 3. Peer written or oral activities. } \\
\text { 4. Students prepare (write or discuss orally) appropriate } \\
\text { responses in small groups (three or four members) } \\
\text { and share them with others. } \\
\text { 5. A member of the group tries to convince other group } \\
\text { members to accept the decision of his/her group. } \\
\text { 6. Student responses are discussed within larger teams. }\end{array}$ & $\begin{array}{l}\text { idea generation, } \\
\text { the ability to solve } \\
\text { problems, } \\
\text { analytical skills, } \\
\text { cooperation } \\
\text { within the groups } \\
\text { and leadership } \\
\text { qualities }\end{array}$ \\
\hline $\begin{array}{l}\text { Team-based } \\
\text { learning }\end{array}$ & $\begin{array}{c}\text { Elementary, } \\
\text { Pre-Intermediate, } \\
\text { Intermediate }\end{array}$ & $\begin{array}{l}\text { 1. Students are given a reading task with an open } \\
\text { ending that is to be completed in a team. } \\
\text { 2. Students discuss their possible variants with } \\
\text { group members to find a proper solution. } \\
\text { 3. Student teams can be given a challenging task, } \\
\text { such as solving a problem or applying theoretical } \\
\text { knowledge in a real-life or professional situation. }\end{array}$ & $\begin{array}{l}\text { ability to give } \\
\text { arguments, usage } \\
\text { of theoretical } \\
\text { knowledge in } \\
\text { practical situations, } \\
\text { imagination, } \\
\text { communicative } \\
\text { abilities } \\
\end{array}$ \\
\hline $\begin{array}{l}\text { Discussions } \\
\text { in small groups }\end{array}$ & $\begin{array}{l}\text { Pre-Intermediate, } \\
\text { Intermediate }\end{array}$ & $\begin{array}{l}\text { 1. A teacher presents a problematic question to } \\
\text { students. } \\
\text { 2. Students discuss, generate ideas, analyze in groups } \\
\text { of five within a certain period of time ( } 15 \text { minutes). } \\
\text { 3. Students share their ideas, present their analysis } \\
\text { and resolutions. }\end{array}$ & $\begin{array}{l}\text { critical thinking, } \\
\text { public speaking, } \\
\text { and active } \\
\text { listening skills }\end{array}$ \\
\hline Group projects & $\begin{array}{l}\text { Intermediate, } \\
\text { Upper- } \\
\text { Intermediate }\end{array}$ & $\begin{array}{l}\text { 1. Student groups prepare projects in professionally } \\
\text { oriented topics. } \\
\text { 2. Projects are presented to other groups. } \\
\text { 2. Projects are peer reviewed (according to the } \\
\text { speaking abilities, use of media, presentation of the } \\
\text { material, originality of ideas). }\end{array}$ & $\begin{array}{l}\text { creative abilities, } \\
\text { elaboration, } \\
\text { presentation } \\
\text { skills, self- } \\
\text { management skills }\end{array}$ \\
\hline
\end{tabular}


Furthermore, it is advisable to change the seating arrangements, use the latest technology, apply modern methods of teaching English [8], and create a comfortable atmosphere and a learner-friendly environment at the lessons. For such purposes it is possible to use discussion forums/boards for asynchronous discussions, Skype, Zoom, online chats for synchronous collaboration, web-based language learning programs etc.

Collaborative learning is beneficial for the modern foreign language learning environment. Collaborative foreign language learning involves students into active participation in the learning process, making them active knowledge builders and autonomous learners. Moreover, usefulness of collaborative learning is that it turns learning into a truly active process, develops critical thinking, public speaking and active listening skills and provides peer interaction and support in learning. Through peer interaction students improve their foreign language competence, cooperation and problem-solving abilities, share their ideas and responsibility, elevate foreign language learning skills, and reflect on the learning results.

The teacher has to implement modern collaborative approaches and strategies which are the most appropriate for a certain group of students. In English classroom environment it is useful to implement such collaborative learning activities as group problem-solving, teambased learning, group projects, brainstorming and others. It is also important to create a learner-friendly environment for successful collaborative learning.

Further researches are connected with the study of future economists' cooperation and collaborative learning via informational technology usage in the process of foreign language training.

\section{СПИСОК ВИКОРИСТАНИХ ДЖЕРЕЛ}

1. Гладун М., Сабліна М. Сучасні онлайн інструменти інтерактивного навчання як технологія співробітництва. Open educational e-environment of modern University. 2018. № 4. C. 33-43. URL: https://openedu.kubg.edu.ua/journal/index.php/openedu/article/view/125/170 (дата звернення: 18.01.2021).

2. Пінчук Л.М. Навчання в співробітництві як ефективна педагогічна технологія у викладанні англійської мови як другої іноземної. Вісник Запорізького національного університету. 2012. № 1(17). C. 66-70. URL: https://web.znu.edu.ua/herald/issues/2012/ped-1-2012/066-70.pdf (дата звернення: 15.01.2021).

3. Сисоєва С. О. Інтерактивні технології навчання дорослих: навчальнометодичний посібник. К.: ВД «ЕКМО», 2011. 324 c. URL: https://kubg.edu.ua/images/stories/Departaments/osvitology/book_sisoevainternet.pdf (дата звернення: 20.01.2021).

4. Bevilacqua M. Collaborative Learning in the Secondary English Class. The Clearing House: A Journal of Educational Strategies, Issues and Ideas. 2000. 73:3. P. 132-133. DOI: 10.1080/00098650009600930.

5. Ibrahim N. et al. The Importance of Implementing Collaborative Learning in the English as a Second Language (ESL) Classroom in Malaysia. Procedia Economics and Finance. 2015. № 31. P. 346-353. DOI: 10.1016/S2212-5671(15)01208-3.

6. Laal M., Ghodsi S. M. Benefits of collaborative learning. Procedia - Social and Behavioral Science. 2012. Vol. 31. P. 486-490. DOI: https://doi.org/10.1016/j.sbspro.2011.12.091.

7. Parupalli R. Collaborative learning in English language classrooms. ACADEMICIA: An International Multidisciplinary Research Journal. 2019. 9(2):5. DOI: 10.5958/2249-7137.2019.00020.

8. Parupalli R. Collaborative Learning In English Language Learning Environment. Research Journal of English Language and Literature. 2019. Vol. 7. Issue 1. DOI: 10.33329/rjelal.7119.330.

9. Scager K., Boonstra J., Peeters T., Vulperhorst J., Wiegant F. Collaborative Learning in Higher Education: Evoking Positive Interdependence. CBE Life Science Education. 2016. 15(4): ar69. DOI: 10.1187/cbe.1607-0219

10. Sousa L., Tiraboschi F., N. do Lago, F. de Figueiredo. Collaborative English Language Learning: Some 
Reflections from Interactions between Pairs. Trab. Linguist. 2019. Vol. 58. No. 1. DOI: https://doi.org/ 10.1590/010318138653439430941.

11. Udvari-Solner A. Collaborative Learning Strategies. Encyclopedia of the Sciences of Learning. Seel N. M. (eds). Encyclopedia of the Sciences of Learning. Springer, Boston, MA, 2012. DOI: https://doi. org/10.1007/978-1-4419-1428-6_818

\section{REFERENCES}

1. Hladun, M., Sablina, M. (2018). Suchasni onlain instrumenty interaktyvnoho navchannia yak tekhnolohiia spivrobitnytstva [Modern online instruments of interactive education as technology of cooperation]. Open educational e-environment of modern University, 4, 33-43. URL: https://openedu.kubg.edu.ua/journal/ index.php/openedu/article/view/125/170 [in Ukrainian].

2. Pinchuk, L. M. (2012). Navchannia v spivrobitnytstvi yak efektyvna pedahohichna tekhnolohiia u vykladanni anhliiskoi movy yak druhoi inozemnoi [Cooperative learning as effective technology in teaching English as second foreign language]. Visnyk Zaporizkoho natsionalnoho universytetu, 1(17), 66-70. URL: https://web.znu.edu.ua/herald/issues/2012/ped-1-2012/066-70.pdf [in Ukrainian].

3. Sysoieva, S. O. (2011). Interaktyvni tekhnolohii navchannia doroslykh. K.: EKMO. URL: https://kubg.edu.ua/images/stories/Departaments/osvitology/book_sisoeva-internet.pdf [in Ukrainian].

4. Bevilacqua, M. (2000). Collaborative Learning in the Secondary English Class. The Clearing House: A Journal of Educational Strategies, Issues and Ideas, 73, 3, 132-133. DOI: 10.1080/00098650009600930

5. Ibrahim, N. et al. (2015). The Importance of Implementing Collaborative Learning in the English as a Second Language (ESL) Classroom in Malaysia. Procedia Economics and Finance, 31, 346-353. DOI: $10.1016 / \mathrm{S} 2212-5671(15) 01208-3$.

6. Laal, M., Ghodsi, S. M. (2012). Benefits of collaborative learning. Procedia - Social and Behavioral Science, 31, 486-490. doi: https://doi.org/10.1016/j.sbspro.2011.12.091

7. Parupalli, R. (2019). Collaborative learning in English language classrooms. ACADEMICIA: An International Multidisciplinary Research Journal, 9(2), 5. DOI: 10.5958/2249-7137.2019.00020.X

8. Parupalli, R. (2019). Collaborative Learning In English Language Learning Environment. Research Journal of English Language and Literature, Vol. 7, Issue 1. DOI: 10.33329/rjelal.7119.330

9. Scager, K., Boonstra, J., Peeters, T., Vulperhorst, J., Wiegant, F. (2016). Collaborative Learning in Higher Education: Evoking Positive Interdependence. CBE Life Science Education, 15(4): ar69. DOI: 10.1187/cbe.16-07-0219

10. Sousa, L., Tiraboschi, F., N. do Lago, F. de Figueiredo. (2019). Collaborative English Language Learning: Some Reflections from Interactions between Pairs. Trab. Linguist., vol. 58, no. 1. doi: https://doi. org/10.1590/010318138653439430941

11. Udvari-Solner, A. (2012). Collaborative Learning Strategies. Seel N. M. (eds). Encyclopedia of the Sciences of Learning, Springer, Boston, MA. doi: https://doi.org/10.1007/978-1-4419-1428-6_818 